\title{
PRODUCTIVE PERFORMANCE OF GROWING LAMBS FED SILAGES OF SUGAR CANE TOPS, SUGAR BEET LEAVES AND GREEN MAIZE STEMS
}

\author{
A. I. A. Suliman ${ }^{1 *}$, A.A. Baiomy ${ }^{2}$ and M.A.A. Awad-Allah ${ }^{3}$ \\ 1- Animal Production Research Institute, Animal Nutrition, Cairo, Egypt, 2- Faculty of Agriculture, \\ SouthValley University, Qena Egypt, 3- Faculty of Specific Education, South Valley University, Qena, Egypt. \\ *Corresponding author:(ahmed_ueepc555@yahoo.com)
}

\section{SUMMARY}

This study was conducted to investigate the performance and nutrient digestibility of sheep fed silage of green maize stems(SGMS), silage of sugar cane tops (SSCT), or silage of sugar beet leaves(SBLS) with concentrate feed mixture (CFM). A total of 16 mature rams $(40-45 \mathrm{~kg}$ live body weight) were used in digestibility trials using one way ANOVA. Twenty four growing Saidi male lambs were used in growth trails. Animals in each trail were randomly divided into four groups according to their body weight. Four diets were used in both experiments. Diet 1 (T1,CFM+berseem hay), diet 2 (T2, CFM+SGMS), diet 3 (T3, CFM+SSCT) and diet 4 (T4, CFM+SSBL). The CFM was used in T1, T2, T3 and T4 as $3 \%$ of live body weight.

Diets containing silage had lower dry matter (DM), organic matter (OM), crude protein (CP), crude fiber $(C F)$, ether extract $(E E)$, and nitrogen free extract (NFE) digestibility coefficients compared to control diet. There were differences $(P<0.01$ and $P<0.001)$ in total digestible nutrient $(T D N)$, digestible and crude protein $(D C P)$ among the studied diets Results of nitrogen balance (NB),nitrogen absorption (NA), NB/NA and NB / total nitrogen consumed $(T N C)$ were significant $(P<0.001)$ in favor of $T 1$. The average daily gain, feed conversion, dressing percentage and other carcass traits were nearly similar among the studied diets. Sheep of T1 had the highest percentage of protein and the lowest percentage of fat in their carcasses meat compared to the other diets.

Keywords: Performance, growing lambs, by-products silages, sugar cane tops, sugar beet leaves, green maize stems

\section{INTORODUCTION}

Berseem (Trifolium alexandrinum) is the main legume winter green forage cultivated in Egypt. Lots of extensive research studies dealt with increasing it'sproductivity and utilization by farm animals even fed as a sole feed ingredient or in combination with other feed ingredients (Suliman, 2001).

In Egypt berseem is cultivated during September and October. The three first cuts are high in moisture content $73-85 \%$, therefore they are not suitable for ensiling (Hamdyet al., 1989). A mixture of berseem / rice straw or berseem / wheat straw in a ratio of $4: 1$ gives better ensiling results (Gabra, et al., 1994). Addition of molasses (4\% of total biomass) improves the fermentation and quality of the silage as well (EL-Kholy, 1981). Berseem yield is estimated by 52 million metric tons per year. It represents $60 \%$ and $75 \%$ of energy and protein available year for ruminants feeding (El-Serafy, 1991). Mixing energy source of feed stuffs with berseem improve its feed utilization (Suliman et al., 2004), which could be preserved as hay or silage (Talha, 1996).

Sugar cane tops contain less nitrogen than the required concentration for optimum fermentation in the rumen. It should be possible to augment the rumen fermentation of cane tops through the use of nitrogen rich supplement(s). Adding urea to cane tops improves the digestibility of organic matter. Cane tops are also poor in phosphorous (Hofke, 1992), which may lead to poor reproductive performance of animals when fed on large quantities without supplementation of phosphorous along with calcium as SCT. Oxalate content in SCT develops calcium utilization deficiency in animals feed.

Daniel (1983), Abd EL-Aziz et al. (1989), Schwarz et al. (1992) and Hermansen and Kirstensen (1993) showed that mixing some agriculture by-products with fodder beet roots is important for making good quality silage to adsorb considerable amount of water from the high moisture roots and reduce protein losses.

The objectives of this study were to determine the effect of feeding silage of green maize stems, sugar cane tops or sugar beet leaves on animal growth performance, feed efficiency and carcass characteristics.

\section{MATERIAL AND METHODS}

The present study was run at the experimental farm of Animal Production Department, Faculty of Agriculture, South Valley University, Qena during the period from March, 2009 to December, 2010). Digestibility trails were conducted to study digestibility, nutritive values, nitrogen balance, performance and carcass characteristics of Saidi lambs, fed different types of silage.

\section{Silage Preparation}

Green maize stems, sugar cane tops, sugar beet leaves, were collected and chopped before ensiling in stack of $2 \times 1.5 \times 1.75$ meters. $1 \%$ common salt, $1.5 \%$ lime stone and $0.5 \%$ ground yellow corn were 
added. Three walls were prepared and spread with plastic sheet before ensiling. After preparing the whole green fodders, the plastic wings were collected together, compressed by a tractor and conserved by $25 \mathrm{~cm}$ layer of the ground to get the anaerobic conditions for 12 weeks.

\section{Digestibility Trails}

A total of 16 mature Saidi rams $\{40$ - $45 \mathrm{~kg}$ live body weight $(\mathrm{LBW})\}$ were applied in digestion trails four animals for each treatment using one way ANOVA. Animals were kept in individual metabolic cages. Each trail lasted 21 days, 14 days as preliminary period and seven days for feces and urine collection. Through the preliminary period each animal was offered $3.5 \mathrm{~kg}$ fresh silage and was then reduced to $3 \mathrm{~kg}$ through the collection (to avoid any refusals) which was offered twice daily (10.00 am and $4.00 \mathrm{pm}$ ) into two equal portions. Fresh water mineral and vitamins mixture blocks were made available all the time. Before feeding, the total excreted feces were weighed and a sample of $10 \%$ of the total daily feces was collected for drying at $60^{\circ} \mathrm{C}$ oven for 24 hours. At the end of the collection period the seven daily fecal samples of each ram were ground and, mixed and kept in nylon bags for laboratory analysis. At the end of the collection period, $5 \%$ of the individual acidified daily urine samples were pooled and sub-samples were subjected for $\mathrm{N}$ - determination.

\section{Feeding Trial}

A sum of 24 growing male Saidi lambs, four months old and $24.4 \pm 1.70 \mathrm{~kg}$ LBW were distributed into four equal groups $(\mathrm{n}=$ six each). All were offered concentrate feed mixture (CFM) as $3 \%$ of their LBW as basal diet in addition to berseem hay $(\mathrm{BH})$ for the control treatment $(\mathrm{T} 1)$, silage of green maize stems (SGMS) for T2, silage of sugar cane tops (SSCT) for T3 and silage of sugar beet leaves (SBLS) for T4. Hay and silage were offered twice daily ad-libtum in two equal portions at $9.00 \mathrm{am}$ and $3.00 \mathrm{pm}$. Offered forages were increased from $1.5 \mathrm{~kg}$ at starting of the experiment to $3.5 \mathrm{~kg}$ at the end of the experiment according to lamb's LBW. Water was made available all the time of the experiment, which extended for 124 days, while weighing was taken place before feeding every two weeks.

\section{Carcass Characteristics}

Three lambs from each group were randomly chosen for carcass characteristics examination. Lambs were fasted for $18 \mathrm{hrs}$ and weighed before slaughtering. After bleeding, they were reweighed and the dressed carcass was longitudinally split into two equal sides. The right side was cut according to the English system of cutting mutton and lamb (Gerracl, 1953). The components of 9,10 and $11^{\text {th }}$ ribs (lean and fat) of the left side of each carcass were mixed and dried at $60^{\circ} \mathrm{C}$ till constant weight other silages this may be due to the dust or ground during collecting the crop in the field or during for moisture determination and preserved in deep freezer for analysis.

\section{Economical Evaluation}

Economical evaluation was done for the tested diet assuming that the price of one $\mathrm{kg} \mathrm{LBW}$ of lambs was 22.00 Egyptian pound (LE) and the price of one $\mathrm{kg}$ DM of CFM, hay, SGMS, SSCT and SSBL were LE 2.00, 0.75, 0.75, 0.75 and 0.70, respectively. The cost of total dry matter intake DMI of CFM plus hay of T1 or silage of T2, T3 and T4 were LE 252.13, 256.73, 256.03 and 258.86, respectively. The experiment was terminated when lambs reached LBW of 40-45 Kg.

\section{Laboratory Analysis}

Analysis of feed, feces and carcass and $\mathrm{N}$ of urine samples were carried out according to A.O.A.C. (1990).

\section{Statistical Analysis}

Data are expressed as mean \pm SE. Statistical analysis was performed using one-way ANOVA. The general liner model (GLM) was applied to test the differences among the four experimental diets. P-values less than 0.05 were considered to be statistically significant (SAS Institute, 2003). Duncan's test was used to examine the significance degrees among means (Duncan, 1955).

The statistical analysis was calculated using the following equation:

$$
\text { Where: } \quad \mathbf{Y}_{\mathrm{ij}}=\boldsymbol{\mu}+\mathbf{T i}+\mathbf{E}_{\mathrm{ij}}
$$

$\mathrm{Y}_{\mathrm{ij}}=$ Experiment observations;

$\mu=$ the overall mean;

$\mathrm{Ti}=$ the effect of dietary treatment;

$\mathrm{i}=1=$ control, $2=\mathrm{CFM}+\mathrm{SGMS}, 3=\mathrm{CFM}+\mathrm{SSCT}$ and $4=\mathrm{CFM}+\mathrm{SSBL}$;

$\mathrm{E}_{\mathrm{ij}}=$ the experimental error.

\section{RESULTSAND DISCUSSION}

\section{Proximate analysis of feeds}

Chemical analysis on dry matter basis indicated that $\mathrm{CFM}$ and $\mathrm{BH}$ were rich in $\mathrm{CP}$ content compared with SSCT and SGMS and SSBL were low in $\mathrm{CF}(\%)$ content compared with $\mathrm{BH}$ and other tested silages. CFM contained greater percentage of NFE than the tested silages.BH and SSCT were characterized by their low content of EE compared with CFM, SGMS and SSBL (Table 1). It is quite accepted that leaves contain greater portions of $\mathrm{CP}$ and lesser portion of CF (Taie, 1998 and Suliman et al., 2001). Silages showed low percentage of NFE than CFM. Forages are characterized by it lower content of NFE and CP, but higher content of CF as a source of structural carbohydrate than concentrates (MARSS, 1997). Moreover some NFE were fermented through ensiling. These results agree with those reported by Suliman et al. (2004). Ash percent was higher in SSBL compared with chopping with the tractor, these results agree with Suliman et al. (2004). 


\section{Nutrients digestibility}

Digestibility coefficients of DM, OM, CP, CF, EE and NFE of the different treatments are presented in (Table 2). Highly significant differences were observed in DM, OM, CP, CF, EE and NFE digestibility coefficients among the studied diets. T1showed higher values compared with other treatments in all nutrients. The lowest digestibility values for all nutrients were detected in T4 compared to T2 and T3. No significant difference was detected between $\mathrm{T} 2, \mathrm{~T} 3$ and $\mathrm{T} 1$ in DM, CF, EE and NFE digestibility. T4 showed the same observation compared with $\mathrm{T} 3$ in $\mathrm{CP}, \mathrm{CF}$ and EE digestibility coefficient except NFE where it was significantly lower inT4 than T3. Hay, SGMS, SSCT, SSBL were offered ad -libtum the amount consumed from these forages represent, 29.7, 44.6, 22.6 and $19 \%$ respectively of the total diet consumed in T1, T2,T3 and T4, respectively. This means that the CFM represents 70.3, 55.4, 77.4 and $81.0 \%$ of the total DMI.

The digestibility's of all nutrients were increased with increasing the concentrate level in the ration. They stated that increasing of dietary energy concentration improved the digestibility of all nutrients, except CF digestibility. Balancing the nutrient content of the diet is a major factor affecting digestibility (Suliman et al., 2001).

Suliman et al. (2004) found no significant difference in $\mathrm{OM}, \mathrm{CF}$ and $\mathrm{EE}$ when fed lambs berseem + SSBL or bean green waste + berseem or SSCT + berseem by 3:1 berseem to byproduct silage, but in $\mathrm{CP}$ and NFE there were highly significant difference $(\mathrm{P}<0.05$ and $\mathrm{P}<0.01)$ among control and other treatments. The results were in favor of silage for CP digestibility. While, for NFE digestibility the figures were in favor of the control treatment.
The results of digestion coefficients can be explained in the light of proximate analysis and portions of silage consumption to CFM, which varied from 29.7:70.3, 44.6:55.4 and 22.6:77.4 to 19.0:81 for T1, T2, T3 and T4, respectively. The greater digestibility coefficients and feeding value of T3 may be due to the higher proportion of CFM in the diet $(77.4 \%)$. While the lower value for T4 may be due to high content of ash (15.72\%) and lower digestibility of most nutrients.

\section{Nutritive Value}

Highly significant differences were detected among studied diets concerning TDN, and DCP, respectively. The highest values were recorded by T1 the lowest TDN value was found in T4. However, the lowest values of DCP were recorded by $\mathrm{T} 2$ (Table 2 ).

No significant difference between $\mathrm{T} 1$ and $\mathrm{T} 3$ was detected in TDN. Suliman and Marzouk, (2006) stated that whole maize silage showed significant difference $(\mathrm{P}<0.05$ and $\mathrm{P}<0.01)$ between CFM and whole maize silage in favor of silage. Such differences might be due to the silage combinations and experimental conditions. The results obtained in this study as TDN and DCP were in accordance with those found by (Abd ELBaki et al., 1997 and Suliman et al., 2004). The nutritive values of tested rations can be explained in view of proximate analysis, portions of silage consumption to CFM and digestibility coefficients (Table 1 and 2).

\section{Nitrogen Balance}

Total nitrogen intake (TNI) differed significantly among the studied diets $\mathrm{T} 1$ showed the highest value, while the lowest was recorded in $\mathrm{T} 2$. TNI was significantly lower compared with T1 (Table 3).

Table 1. Proximate analysis of feeds and rations used in this experiment

\begin{tabular}{lcccccc}
\hline \multirow{2}{*}{ Treatment } & \multicolumn{6}{c}{ Nutritional composition types on DM basis } \\
\cline { 2 - 7 } & OM & CP & CF & EE & NFE & ASH \\
\hline CFM & 87.35 & 15.52 & 12.21 & 2.69 & 56.93 & 12.65 \\
BH & 84.66 & 15.36 & 31.37 & 0.95 & 36.98 & 15.34 \\
SGMS & 87.71 & 9.35 & 36.29 & 2.39 & 39.68 & 12.29 \\
SSCT & 86.98 & 6.14 & 31.85 & 1.60 & 47.39 & 13.02 \\
SSBL & 71.13 & 11.15 & 11.28 & 3.45 & 45.25 & 28.87 \\
Diets & & & & & & \\
T1 (CFM+HAY) & 86.58 & 15.47 & 17.93 & 2.18 & 51.00 & 13.42 \\
T2 (CFM+SGMS) & 87.40 & 12.77 & 22.96 & 2.43 & 49.24 & 12.60 \\
T3 (CFM+SSCT) & 87.27 & 13.40 & 16.65 & 2.45 & 54.77 & 12.73 \\
T4 (CFM+SSBL) & 84.28 & 14.69 & 12.04 & 2.84 & 54.71 & 15.72 \\
\hline WH
\end{tabular}

Where: $\mathrm{CFM}=$ concentrate feed mixture, $\mathrm{BH}=$ berseem hay, SGMS = silage of green maize stems, $\mathrm{SSCT}=$ silage of sugar cane tops, SSBL = silage of sugar beet leaves.

The concentrate feed mixture (CFM) consisted of (cotton seed meal $8 \%$, rice gluten meal $7 \%$, soybean meal $3 \%$, wheat bran $21 \%$, rice bran $18 \%$, ground maize $25 \%$, molasses $15 \%$, lime stone $2.5 \%$ and salt $0.5 \%$ ). 
Table 2. Least square Means \pm standard errors Nutrients digestibility coefficients and nutritive values for rams fed on different types of silage

\begin{tabular}{|c|c|c|c|c|c|c|}
\hline & \multicolumn{4}{|c|}{ Nutrients digestibility coefficients } & \multirow{2}{*}{$\pm \mathbf{S E}$} & \multirow{2}{*}{ Sig } \\
\hline & T1 & $\mathbf{T} 2$ & T3 & $\mathbf{T 4}$ & & \\
\hline No. of animals & 4 & 4 & 4 & 4 & & \\
\hline \multicolumn{7}{|l|}{ Digestibility (\%) } \\
\hline DM & $63.96^{\mathrm{a}}$ & $54.45^{\mathrm{b}}$ & $57.12^{\mathrm{ab}}$ & $46.95^{\mathrm{c}}$ & 2.28 & $* *$ \\
\hline $\mathrm{OM}$ & $64.20^{\mathrm{a}}$ & $53.08^{\mathrm{cb}}$ & $56.95^{\mathrm{b}}$ & $46.30^{\mathrm{c}}$ & 2.24 & $* * *$ \\
\hline $\mathrm{CP}$ & $60.90^{\mathrm{a}}$ & $43.55^{\mathrm{b}}$ & $51.39^{\mathrm{b}}$ & $43.93^{\mathrm{b}}$ & 2.94 & $* *$ \\
\hline $\mathrm{CF}$ & $50.66^{\mathrm{a}}$ & $47.20^{\mathrm{a}}$ & $42.28^{\mathrm{ab}}$ & $32.75^{\mathrm{b}}$ & 3.06 & $* *$ \\
\hline $\mathrm{EE}$ & $62.28^{\mathrm{a}}$ & $53.54^{\mathrm{ab}}$ & $52.11^{\mathrm{ab}}$ & $51.23^{\mathrm{b}}$ & 3.56 & $*$ \\
\hline NFE & $69.74^{\mathrm{a}}$ & $57.74^{\mathrm{b}}$ & $64.43^{\mathrm{a}}$ & $57.12^{\mathrm{b}}$ & 2.11 & $* * *$ \\
\hline \multicolumn{7}{|l|}{ Nutritive Values } \\
\hline TDN & $57.12^{\mathrm{a}}$ & $47.76^{\mathrm{bc}}$ & $54.09^{\mathrm{ab}}$ & $44.91^{\mathrm{c}}$ & 1.95 & $* *$ \\
\hline DCP & $9.42^{\mathrm{a}}$ & $5.56^{\mathrm{c}}$ & $6.89^{\mathrm{b}}$ & $6.45^{\mathrm{b}}$ & 2.20 & $* *$ \\
\hline
\end{tabular}

$\mathrm{T} 1=$ control $(\mathrm{CFM}+$ berseem hay $), \mathrm{T} 2=(\mathrm{CFM}+\mathrm{SGMS}), \mathrm{T} 3=(\mathrm{CFM}+\mathrm{SSCT})$ and $\mathrm{T} 4=(\mathrm{CFM}+\mathrm{SSBL})$

CFM was used in T1, T2, T3 and T4 as $3 \%$ of live body weight.

a,b,c means within the same row with different litters differ significantly at $\mathrm{P}<0.05$.

* Significant 0.05), ** Significant $(\mathrm{P}<0.01)$, *** Significant $(\mathrm{P}<0.001)$

Table 3.Least square Means \pm standard errors of nitrogen balance and nitrogen absorption values for rams fed on different types of silage

\begin{tabular}{|c|c|c|c|c|c|c|c|}
\hline Parameters & No & T1 & $\mathbf{T} 2$ & T3 & T4 & $\pm \mathbf{S E}$ & Sig \\
\hline \multicolumn{8}{|l|}{ Nitrogen intake } \\
\hline Nitrogen in hay or silage $\mathrm{g} / \mathrm{day}$ & 16 & $6.22^{\mathrm{a}}$ & $4.82^{\mathrm{b}}$ & $2.01^{\mathrm{c}}$ & $3.06^{\mathrm{c}}$ & 0.26 & $* * *$ \\
\hline Nitrogen in CFM & 16 & $21.13^{\mathrm{b}}$ & $17.93^{\mathrm{c}}$ & $22.41^{\mathrm{a}}$ & $22.41^{\mathrm{a}}$ & 0.00 & $* * *$ \\
\hline Total nitrogen. intake (TNI) & 16 & $27.35^{\mathrm{a}}$ & $22.75^{\mathrm{c}}$ & $24.42^{\mathrm{b}}$ & $25.47^{\mathrm{b}}$ & 0.26 & $* * *$ \\
\hline \multicolumn{8}{|l|}{ Nitrogen execration } \\
\hline Nitrogen in feces & 16 & $10.69^{\mathrm{b}}$ & $12.38^{\mathrm{ab}}$ & $11.88^{\mathrm{b}}$ & $14.83^{\mathrm{a}}$ & 0.65 & $* *$ \\
\hline Nitrogen in urine & 16 & $5.79^{\mathrm{c}}$ & $5.14^{\mathrm{b}}$ & $5.00^{\mathrm{b}}$ & $3.75^{\mathrm{a}}$ & 0.14 & $*$ \\
\hline Total Nitrogen execration & 16 & $16.48^{\mathrm{b}}$ & $17.52^{\mathrm{b}}$ & $16.88^{\mathrm{b}}$ & $18.58^{\mathrm{a}}$ & 0.72 & $* * *$ \\
\hline Nitrogen balance (NB) & 16 & $10.87^{\mathrm{a}}$ & $5.23^{\mathrm{c}}$ & $7.54^{\mathrm{b}}$ & $6.89^{\mathrm{b}}$ & 0.86 & $* * *$ \\
\hline Nitrogen absorbed (NA) & 16 & $16.66^{\mathrm{a}}$ & $10.37^{\mathrm{c}}$ & $12.54^{\mathrm{b}}$ & $10.64^{\mathrm{c}}$ & 0.79 & $* * *$ \\
\hline $\mathbf{N B} / \mathbf{N A}$ & 16 & $65.25^{\mathrm{a}}$ & $50.43^{\mathrm{b}}$ & $60.13^{\mathrm{a}}$ & $64.76^{\mathrm{a}}$ & 1.59 & $* * *$ \\
\hline NB/ TNI & 16 & $39.74^{\mathrm{a}}$ & $22.99^{\mathrm{c}}$ & $30.88^{\mathrm{b}}$ & $27.05^{\mathrm{c}}$ & 2.90 & $* * *$ \\
\hline
\end{tabular}

$\mathrm{T} 1=$ control $(\mathrm{CFM}+$ berseem hay $), \mathrm{T} 2=(\mathrm{CFM}+\mathrm{SGMS}), \mathrm{T} 3=(\mathrm{CFM}+\mathrm{SSCT})$ and $\mathrm{T} 4=(\mathrm{CFM}+\mathrm{SSBL}) \mathrm{CFM}$ was used in $\mathrm{T} 1, \mathrm{~T} 2, \mathrm{~T} 3$ and $\mathrm{T} 4$ as $3 \%$ of live body weight.

${ }^{\mathrm{a}, \mathrm{b}, \mathrm{c}}$ Means denoted within the same row with different superscripts are significantly differ at $\mathrm{P}<0.05$.

* Significant $(\mathrm{P}<0.05), * *$ significant $(\mathrm{P}<0.01), * * *$ significant $(\mathrm{P}<0.001)$

Results of nitrogen excreted in feces differed significantly among treatments. The highest value of nitrogen balance was recorded in $\mathrm{T} 1$, while the lowest value was recorded in $\mathrm{T} 2$. T1 showed higher $(\mathrm{P}<0.001)$ value of nitrogen balance $(\mathrm{NB})$, balance/nitrogen absorbed (NB/NA) than T2 (Table 3).

The results of nitrogen Balance (NB) gm/ day, $\mathrm{NB} /$ nitrogen absorbed (NA) $\%$ and NB/total nitrogen intake \% (TNI) were in accordance with proximate analysis, nitrogen digestibility and DCP (Tables 1 and 2). Lambs fed T2 (SGMS) showed the lowest value of NB $5.23 \mathrm{~g} /$ head /day, DCP 5.56 $\mathrm{gm} / \mathrm{head} /$ day, total $\mathrm{CP}$ consumed 22.75 $\mathrm{gm} / \mathrm{head} /$ day among other treatments. The lowest value of $\mathrm{N}$ - consumed and the lowest digestibility of $\mathrm{CP}$ observed in rams fed $\mathrm{T} 2$ than other treatments may explain the significant depression in $\mathrm{N}$-balance and DCP when rams fed T2. These results were in agreement with those of Gunter $e t$ al. (1998) and Ghanem et al. (2000).

\section{Feeding Trial}

\section{Average daily gain}

Significant $(\mathrm{P}<0.05)$ differences were found among the experimental groups in total body weight gain the figures (Table 4). The final body weight (FBW) values were slightly higher for hay containing diets compared with those fed silages 
plus CFM; subsequently the daily gain came out greater in lambs fed hay than the other treatments. This phenomena may be due to the higher digestibility, feeding value and intake of TDN and
DCP in T1 than other treatments, and efficient utilization of hay and it's rumen fermentation products volatile fatty acids, $\mathrm{NH}_{3}$ and microbial protein (EL-Bedawy et al., 1994).

Table 4. Least square Means \pm standard errors of growth performance and feed conversion for rams fed on different types of silage

\begin{tabular}{|c|c|c|c|c|c|c|c|}
\hline Items & No. & $\mathbf{T 1}$ & $\mathbf{T 2}$ & T3 & T4 & $\pm \mathrm{SE}$ & Sig \\
\hline IBW (kg) & 24 & 23.33 & 25.83 & 24.17 & 24.17 & 1.7 & NS \\
\hline FBW (kg) & 24 & 44.17 & 41.67 & 44.17 & 43.33 & 1.15 & NS \\
\hline $\mathrm{TG}(\mathrm{kg})$ & 24 & $20.83^{\mathrm{a}}$ & $15.33^{\mathrm{c}}$ & $20.00^{\mathrm{a}}$ & $19.17^{\mathrm{ab}}$ & 1.48 & $*$ \\
\hline $\mathrm{DG}(\mathrm{g})$ & 24 & $168.0^{\mathrm{a}}$ & $127.69^{b}$ & $161.29^{\mathrm{ab}}$ & $154.47^{\mathrm{ab}}$ & 11.93 & $*$ \\
\hline \multicolumn{8}{|l|}{ Feed consumption: } \\
\hline $\mathrm{kg}$ DM of CFM & 24 & 112.43 & 113.52 & 115.34 & 112.87 & 3.31 & NS \\
\hline $\begin{array}{l}\mathrm{kg} \mathrm{DM} \text { of hay or } \\
\text { silage }\end{array}$ & 24 & $36.36^{\mathrm{cb}}$ & $39.58^{\mathrm{b}}$ & $33.87^{\mathrm{c}}$ & $47.32^{\mathrm{a}}$ & 1.82 & $* * *$ \\
\hline Total (DMI) kg & 24 & $148.79^{b}$ & $153.10^{\mathrm{ab}}$ & $149.21^{\mathrm{b}}$ & $160.19^{\mathrm{a}}$ & 3.11 & $*$ \\
\hline TDN (kg) & 24 & $84.99^{\mathrm{a}}$ & $73.12^{\mathrm{c}}$ & $80.71^{b}$ & $71.94^{\mathrm{c}}$ & 1.60 & $* * *$ \\
\hline $\mathrm{DCP}(\mathrm{kg})$ & 24 & $14.02^{\mathrm{a}}$ & $8.51^{b}$ & $10.28^{\mathrm{ab}}$ & $10.33^{\mathrm{ab}}$ & 1.70 & $* *$ \\
\hline \multicolumn{8}{|l|}{ Feed conversion: } \\
\hline DM $(\mathrm{kg}) / \mathrm{kg}$ gain & 24 & $7.14^{\mathrm{b}}$ & $9.67^{\mathrm{a}}$ & $7.46^{\mathrm{b}}$ & $8.36^{\mathrm{a}}$ & 0.69 & $*$ \\
\hline TDN $(\mathrm{kg}) / \mathrm{kg}$ gain & 24 & $4.08^{\mathrm{ab}}$ & $4.62^{\mathrm{a}}$ & $4.04^{\mathrm{ab}}$ & $3.76^{\mathrm{b}}$ & 0.38 & $* * *$ \\
\hline DCP $(\mathrm{kg}) / \mathrm{kg}$ gain & 24 & $0.67^{\mathrm{a}}$ & $0.54^{\mathrm{ab}}$ & $0.51^{b}$ & $0.54^{\mathrm{ab}}$ & 0.11 & $* * *$ \\
\hline
\end{tabular}

$\mathrm{T} 1=$ control $(\mathrm{CFM}+$ berseem hay $), \mathrm{T} 2=(\mathrm{CFM}+\mathrm{SGMS}), \mathrm{T} 3=(\mathrm{CFM}+\mathrm{SSCT})$ and T4 $=(\mathrm{CFM}+\mathrm{SSBL}) \mathrm{CFM}$ was used in T1, $\mathrm{T} 2, \mathrm{~T} 3$ and $\mathrm{T} 4$ as $3 \%$ of live body weight.

a,b,c Means denoted within the same row with different superscripts are significantly differ at $\mathrm{P}<0.05$.

* Significant $(\mathrm{P}<0.05), * *$ Significant $(\mathrm{P}<0.01), * * *$ Significant $(\mathrm{P}<0.001)$

Table 5. Economic coasts for growth performance for rams fed on different types of silage

\begin{tabular}{lcccc}
\hline Economical evaluation & T1 & T2 & T3 & T4 \\
\hline Cost of kg DMI of CFM (LE) & 2.00 & 2.00 & 2.00 & 2.00 \\
Total feed intake kg & 148.79 & 153.10 & 149.21 & 160.19 \\
Cost of total feed intake(LE) (b) & 252.13 & 256.73 & 256.08 & 258.86 \\
Price of kg LBW(LE) & 22.00 & 22.00 & 22.00 & 22.00 \\
Price of total gain (a) & 458.26 & 337.26 & 440 & 421.74 \\
Revenue (LE) & 206.13 & 80.53 & 183.92 & 162.88 \\
Economical efficiency $(\mathbf{y})$ & 0.81 & 0.31 & 0.71 & 0.62 \\
\hline
\end{tabular}

$\mathrm{T} 1=$ control $(\mathrm{CFM}+$ berseem hay $), \mathrm{T} 2=(\mathrm{CFM}+\mathrm{SGMS}), \mathrm{T} 3=(\mathrm{CFM}+\mathrm{SSCT})$ and $\mathrm{T} 4=(\mathrm{CFM}+\mathrm{SSBL})$

CFM was used in T1, T2, T3 and T4 as $3 \%$ of live body weight.

Economic efficiency, $\mathrm{y}=\{(\mathrm{a}-\mathrm{b}) / \mathrm{b})\}$, where $\mathrm{a}=$ selling coast the obtain gain $\mathrm{and} \mathrm{b}=$ feeding coast of this gain

\section{Feed efficiency}

Highly significant differences $(\mathrm{P}<0.001)$ were found among treatments concerning feed consumption or total dry matter intake. Significant difference was detected in feed conversion as DM between $\mathrm{T} 2$ and $\mathrm{T} 4$ vs. $\mathrm{T} 1$ and $\mathrm{T} 3$ (Table 4). Results for TDN and DCP $\mathrm{kg} / \mathrm{kg}$ gain showed significant differences $(\mathrm{P}<0.001)$. The more efficient feed conversion ratio as DM was observed in $\mathrm{T} 1$, while the lowest feed conversion ratio expressed as $\mathrm{kg}$
TDN/kg gain was observed in T4. This means that feed consumption was the effective factor affecting feed conversion when gain was not significantly differed. The lower DCP consumption of animals fed silage containing diet (Table 4) may explain the better feed conversion expressed as $\mathrm{kg}$ DCP $/ \mathrm{kg}$ gain These results agree with those found by (Suliman et al., 2004) on different types of berseem +green bean steams, berseem + SSBL and berseem + SSCT. The greater amounts consumed from TDN, and DCP for the control diet can be 
explained in the light of proximate analysis, digestibility and nutritive values (Tables 1 and 2).

\section{Economical evaluation}

Coast of total feed intake was higher in $\mathrm{T} 4$, than other treatments (Table 5), while higher revenue was for T1 and T3 (Table 5). Ration containing hay showed better economic efficiency because of the better daily gain and feed conversion efficiency than lambs fed ration containing silages (Table 5).

Table 6. Least square Means \pm standard errors carcass traits and carcass cuts for lambs fed on different types of silage

\begin{tabular}{|c|c|c|c|c|c|c|c|}
\hline Parameters & No. & T1 & $\mathbf{T} 2$ & $\mathbf{T 3}$ & T4 & $\pm \mathbf{S E}$ & Sig \\
\hline Fasting body weight(kg) & 12 & $42.33^{\mathrm{b}}$ & $44.33^{\mathrm{ab}}$ & $45.67^{\mathrm{a}}$ & $41.67^{\mathrm{b}}$ & 0.88 & $* *$ \\
\hline Carcass length $(\mathrm{cm})$ & 12 & $50.33^{c}$ & $56.00^{\mathrm{b}}$ & $64.00^{\mathrm{a}}$ & $65.33^{\mathrm{a}}$ & 1.62 & $* * *$ \\
\hline Carcass circumference $(\mathbf{c m})$ & 12 & 72.67 & 79.50 & 71.67 & 65.00 & 5.17 & NS \\
\hline $\begin{array}{l}\text { Width of carcass at lion } \\
\text { (cm) }\end{array}$ & 12 & 21.00 & 21.67 & 21.33 & 20.67 & 0.65 & NS \\
\hline carcass weight $(\mathrm{kg})(\mathrm{CW})$ & 12 & 22.83 & 23.00 & 23.40 & 20.80 & 0.99 & NS \\
\hline Empty dressing (\%) & 12 & 65.12 & 61.34 & 60.28 & 60.16 & 1.67 & NS \\
\hline Fast dressing (\%) & 12 & 53.63 & 52.12 & 51.07 & 49.90 & 1.10 & NS \\
\hline Tail fat (kg) & 12 & 0.65 & 0.55 & 0.65 & 0.47 & 0.08 & NS \\
\hline Bowel fat (kg) & 12 & $0.15^{\mathrm{b}}$ & $0.22^{\mathrm{b}}$ & $0.30^{\mathrm{a}}$ & $0.15^{\mathrm{b}}$ & 0.02 & $* * *$ \\
\hline Kidney fat (kg) & 12 & $0.12^{\mathrm{b}}$ & $0.15^{\mathrm{ab}}$ & $0.25^{\mathrm{a}}$ & $0.13^{\mathrm{ab}}$ & 0.04 & $*$ \\
\hline Total fat (kg) & 12 & $0.92^{\mathrm{ab}}$ & $0.92^{\mathrm{ab}}$ & $1.20^{\mathrm{a}}$ & $0.75^{b}$ & 0.09 & $* *$ \\
\hline Fore quarter (kg) & 12 & 5.42 & 5.27 & 5.45 & 4.73 & 0.26 & NS \\
\hline Hind quarter (kg) & 12 & 4.97 & 5.48 & 5.13 & 4.83 & 0.22 & NS \\
\hline Fore quarter (\%) & 12 & $52.00^{\mathrm{a}}$ & $48.97^{\mathrm{b}}$ & $51.44^{\mathrm{a}}$ & $49.47^{\mathrm{b}}$ & 0.27 & $* * *$ \\
\hline Hind quarter (\%) & 12 & $47.83^{\mathrm{b}}$ & $51.03^{\mathrm{a}}$ & $48.56^{\mathrm{b}}$ & $50.53^{\mathrm{a}}$ & 0.23 & $* * *$ \\
\hline Shoulder weight. (kg) & 12 & 2.06 & 1.98 & 1.97 & 1.80 & 0.12 & NS \\
\hline Sets cut (kg) & 12 & 1.50 & 1.75 & 1.47 & 1.53 & 0.09 & NS \\
\hline Ends cut (kg) & 12 & $1.33^{\mathrm{b}}$ & $1.08^{\mathrm{c}}$ & $1.53^{\mathrm{a}}$ & $1.00^{\mathrm{c}}$ & 0.06 & $* * *$ \\
\hline Chine weight (kg) & 12 & 1.63 & 1.82 & 1.50 & 1.43 & 0.13 & NS \\
\hline Leg weight (kg) & 12 & 3.30 & 3.67 & 3.63 & 3.40 & 0.19 & NS \\
\hline Chine (\%) & 12 & 32.70 & 33.15 & 29.54 & 29.50 & 2.38 & NS \\
\hline $\operatorname{Leg}(\%)$ & 12 & 67.30 & 66.85 & 70.46 & 70.47 & 2.37 & NS \\
\hline Length rump (cm) & 12 & 48.33 & 48.67 & 51.00 & 49.33 & 1.04 & NS \\
\hline $\begin{array}{l}\text { Circumference of rump } \\
\text { (cm) }\end{array}$ & 12 & $41.67^{\mathrm{b}}$ & $48.00^{\mathrm{a}}$ & $45.00^{\mathrm{ab}}$ & $49.00^{\mathrm{a}}$ & 1.20 & $* * *$ \\
\hline $\begin{array}{l}\text { Area of Longismus dorsi } \\
\left(\mathrm{cm}^{2}\right)\end{array}$ & 12 & $22.53^{\mathrm{a}}$ & $15.44^{\mathrm{b}}$ & $24.25^{\mathrm{a}}$ & $14.56^{\mathrm{b}}$ & 2.01 & $* *$ \\
\hline $\begin{array}{l}\text { Fat thickness around } \\
\text { Longismus dorsi (mm) }\end{array}$ & 12 & $0.62^{\mathrm{a}}$ & $0.71^{\mathrm{a}}$ & $0.44^{\mathrm{b}}$ & $0.73^{\mathrm{a}}$ & 0.04 & $* * *$ \\
\hline
\end{tabular}

$\overline{\mathrm{CW}}=$ carcass weight $(\mathrm{kg}), \mathrm{EDr}=$ Empty dressing $(\%), \mathrm{FDr}=$ Fast dressing $(\%)$, Sets = chest \&neck, ends = fore pairs ribs cut , chine $=$ lion weight, leg $=$ rump weight. Where: $\mathrm{T} 1=$ control $(\mathrm{CFM}+$ berseem hay $), \mathrm{T} 2=(\mathrm{CFM}+\mathrm{SGMS}), \mathrm{T} 3=$ $(\mathrm{CFM}+\mathrm{SSCT})$ and $\mathrm{T} 4=(\mathrm{CFM}+\mathrm{SSBL}), \mathrm{CFM}$ was used in $\mathrm{T} 1, \mathrm{~T} 2, \mathrm{~T} 3$ and $\mathrm{T} 4 \mathrm{as} 3 \%$ of live body weight.

\section{Carcass characteristics}

Highly significant $(\mathrm{P}<0.01 \& \quad \mathrm{P}<0.001)$ differences were found among lambs in fasting body weight $(\mathrm{FBW}) \mathrm{kg}$ and carcass length $(\mathrm{cm})$, while no significant difference was observed in carcass weight and dressing percentage calculated based on fasted (FDr) or empty weights (EDr \%) (Table 6).

Fore and hind quarters as well as tail fat weights were not affected by treatments. No significant difference $(\mathrm{P}<0.001)$ was also found among treatments in leg and chine weights (Table
6). Carcass lambs of $\mathrm{T} 3$ and $\mathrm{T} 1$ recorded the highest weight of ends compared with those fed T2 and T4. The highest weights of shoulder were recorded in $\mathrm{T} 1$ while the lowest value was for T4. Measurements of rump circumference area of Longismus dorsi and fat thickness around Longismus dorsi differed significantly among the studied groups. Lambs fed T4 and T2 recorded the highest value for rump circumference and fat thickness. The highest area of Longismus dorsi $(\mathrm{cm})^{2}$ was recorded in $\mathrm{T} 3$ and $\mathrm{T} 1$ (Table 6). 
Physical analysis of 9,10 and $11^{\text {th }}$ ribs cut (lean, fat and bone) indicated significant differences $(\mathrm{P}<0.05)$ in favor of $\mathrm{T} 1$ than the other treatment.

Chemical composition of Longismus dorsi muscle indicated highly significant differences $(\mathrm{P}<0.01 \& \mathrm{P}<0.05)$ in protein and $\mathrm{EE}$ (Table 8$)$.

The dietary protein and carbohydrates are the two main components, to be effective on animal performance (Taie et al., 1996). They positively affect rumen fermentation subsequently the nutrient utilization (Mahmoud et al., 1999). In this view we can explain carcass characteristics of fat tail lambs. Animals fed $\mathrm{T} 1$ that was greater than other treatments in $\mathrm{CP}$ and NFE\% showed better final body weight, total gain and fasting body weight. Also eye muscle area was affected by the two main factors. Fat are the main element that reflect the nutritional status of the animal (Taie et al., 1996 and Suliman and Marzouk, 2006). The fat content of longismus dorsi was greater for animals fed $\mathrm{T} 1$ than other treatments. The second factor is the genetic structural especially growth cycle waves, first come from the head of animal toward lion area and the second wave come from down raised up to lion area (rump).

Table 7. Least square means \pm Standard error of 9, 10 and 11 ribs cut weight for lambs fed on different types of silage

\begin{tabular}{|c|c|c|c|c|c|c|c|}
\hline ITEMS & No. & T1 & $\mathbf{T 2}$ & T3 & T4 & $\pm \mathbf{S E}$ & Sig \\
\hline $\begin{array}{l}\text { Total WT of sample } \\
\text { (gm). }\end{array}$ & 12 & $526.7^{\mathrm{a}}$ & $450.0^{\mathrm{ab}}$ & $483.3^{\mathrm{ab}}$ & $400.0^{\mathrm{b}}$ & 35.9 & $*$ \\
\hline Lean meat wt. (gm) & 12 & $341.7^{\mathrm{a}}$ & $291.7^{\mathrm{ab}}$ & $310.3^{\mathrm{ab}}$ & $250.0^{\mathrm{b}}$ & 22.3 & $*$ \\
\hline Fat wt. (gm) & 12 & 105.0 & 90.0 & 99.7 & 87.0 & 8.5 & NS \\
\hline Bone wt. (gm) & 12 & $81.7^{\mathrm{a}}$ & $68.3^{\mathrm{ab}}$ & $73.3^{\mathrm{ab}}$ & $63.3^{\mathrm{b}}$ & 5.1 & $*$ \\
\hline
\end{tabular}

Table 8. Means \pm Standard errors of the chemical composition of Longismus dorsi for rams fed on different types of silage

\begin{tabular}{lccccccc}
\hline ITEMS & No. & T1 & T2 & T3 & T4 & 土 SE & Sig \\
\hline Moisture \% & 12 & $63.17^{\mathrm{b}}$ & $67.30^{\mathrm{b}}$ & $62.63^{\mathrm{b}}$ & $72.04^{\mathrm{a}}$ & 2.22 & $*$ \\
CP \% & 12 & $20.64^{\mathrm{a}}$ & $20.51^{\mathrm{a}}$ & $21.27^{\mathrm{a}}$ & $14.22^{\mathrm{b}}$ & 3.02 & $* *$ \\
EE \% & 12 & $14.86^{\mathrm{a}}$ & $10.92^{\mathrm{b}}$ & $14.76^{\mathrm{a}}$ & $12.40^{\mathrm{a}}$ & 2.04 & $*$ \\
Ash \% & 12 & 1.33 & 1.29 & 1.35 & 1.34 & 0.14 & NS \\
\hline
\end{tabular}

$\mathrm{CP}=$ Crudeprotein, $\mathrm{EE}=$ Ether extract.

$\mathrm{T} 1=$ control $(\mathrm{CFM}+$ berseem hay $), \mathrm{T} 2=(\mathrm{CFM}+\mathrm{SGMS}), \mathrm{T} 3=(\mathrm{CFM}+\mathrm{SSCT})$ and $\mathrm{T} 4=(\mathrm{CFM}+\mathrm{SSBL})$

CFM was used in T1, T2, T3 and T4 as $3 \%$ of live body weight.

${ }^{\mathrm{a}, \mathrm{b}, \mathrm{c}}$ Means denoted within the same row with different superscripts are significantly differ at $\mathrm{P}<0.05$.

* Significant $(\mathrm{P}<.05)$, ** significant $(\mathrm{P}<0.01)$.

\section{CONCLUSION}

Lambs fed the control diet showed better results expressed as digestibility, feeding value, $\mathrm{N}$-balance, growth performance and economical efficiency. More work is required to improve the digestibility and feeding value of silage containing diets.

\section{REFERENCES}

A.O.A.C., 1990. Official Methods of Analysis $\left(12^{\text {th }}\right.$ ed). Association of official analytical chemist, Washington, D.C.

Abd EL-Baki, S.M., A. Zaki, S.M Bassunyand K.M.EL-Gindy, 1997. Nutritional Studies on some forages in Egypt, Silage from fodder beet roots and leaves for sheep and rabbits. Egyptian Journal Nutrition and feeds, 1, Special Issue, 133-143.

Abdul-Aziz, G.M., A.M. Ramah, A.S. Shalaby, and M.G. Be shay, 1989. Evaluation of Jar Made silage from different fodder beet varieties either alone or with some Roughages. Third Egyptian - British conference on Animal, Fish and Poultry Production, Alexandria, 7-10 October 1989, 153-160.

Daniel, D., 1983. Mixed silage from grass fodder beet and straw. Wirbschafb scigene, 29 (1) 2636 Nutrition Abstract and Review, 54: 459.

Duncan, D.B., 1955. Multiple range and multiple F.tests. Biometrics, 11:1042. 
El-Bedawy, A.Y., 1994. Effect of dietary roughage levels on the lactation, performance of Egyptian goats. Egyptian Journal of Animal Prod., 31: 111-124.

El-Kholy, S.G., 1981. The nutritive value and feeding quality of green forage and hay from successive cuts of interested clover with Italian rye grass fed to mature rams and growing sheep with reference to yield to output at northern Delta. M.Sc. Thesis, Faculty of Agriculture Mansoura University.

EL-Serafy, M.A., 1991. Efficiency of Utilization of Egyptian clover in milk and meat production in two animal production systems in Egypt during year 1985-1990 proceeding of the $3^{\text {rd }}$ Scientific Symposium for animals, poultry and fish nutrition: Sakha - Kafre EL-Shake, 26-28 November (1991):119-133.

Gerracl, F., 1953. English Methods of cutting Mutton and lambs. The production and marketing beef meat. Processing of the third study meeting of European Association for Animal Production. Publication. No.4 Siena, Rome.

Gabra, M. A., S. I. Hafez and B.B. Matter, 1994. Comparative study of voluntary intake and feeding qualities of some annual and perennial forage fed to cattle, sheep and goats. Journal of Agriculture Science Mansoura University, 19: 507-521.

Gunter, S.A., M.L. Galyean and K.J. MalcolmCallis, 1998. Factors influencing the performance of lot steers limit- feed high concentrate diets. Prof. Anim. Sci., 12: 167-175.

Ghanem, G.H.A., E.A. Amer and F.A. EL-Zeer, 2000. Evaluation of using Maize Stover silage by sheep. Journal Agriculture Tanta University, 591:603.

Hamdy, S.M., S.M. Ahmed, A.Z. EL-Basiony and A. EL-Serafy, 1989.Evaluation of some winter field crops by- products, water hyacinth and berseem hay. Annals Agriculture Science Faculty of Agriculture. Ain Shams University, Egypt, 34: 1021-1032.

Hermansen, J.E. and Kristensen,1993. The effect of supplementing formalin treated soya-bean meal on feed intake, milk yield and live weight gain of dairy cows fed ensiled fodder beet Archives of Animal Nutrition 43:3, 245-256.

Hofke, J., 1992. Studies on the effect of different Berseem - straw rations on the digestion and milk production efficiency of water buffaloes in Egypt- Diploma Thesis. Institute of Animal
Production in the tropics and subtropics of the University of. Hohenheim, Stuttgart.

Mahmoud, A.M., M.M. Bendary, M.A. Harfoush and Ramadan, 1999. Effect of feeding lactating cows corn silage on milk production compared with traditional summer and winter rations. Journal Agriculture Science Mansoura University, 17: 2904U.

Ministry of Agriculture and Reclaimed Sand Soil; Agriculture Research Center;Animal Production Research Institute,1997. Book of Application and Scientific Animal Nutrition first Edition, 1997.

SAS Institute, 2003. SAS User's Guide. Version 9.1 SAS Institute Inc., Cary, NC.

Schwarz, F.J., E. Pex and M. Kirchgessner, 1992. Nutritive value of mixed fodder beet silage from dairy cows. Nutrition Abstract and Review 62, 357.

Suliman, A.I.A., 2001. Studies on using some green forages in sheep feeding. Ph.D., Science Faculty of Agriculture Animal Production Department El-Minia University.

Suliman, A.I.A. S.M.S Mustafa, and K.M. Marzouk, 2004. Effect of feeding silage of berseem mixed with some agriculture byproducts on digestibility and performance of sheep. Minia Journal of Agriculture Research and Development, Vol. (24) No. 4 pp 737- 752.

Suliman, A.I.A. and K.M. Marzouk, 2006. Nutritional value and economical efficiency of whole maize silage for fattening lambs and carcass characteristics Journal of Agriculture Science Mansoura University Vol.31 No. (10):6207 - 6215 .

Soliman, A. A., A.I.A. Suliman and A.A. Biomy, 2007. Productive performance of growing lambs fed on urea treated silage and concentrate. Journal of Agriculture Science Mansoura University., 32(7): 5213 -5223.

Taie, H. T.,1998. Effect of dietary levels of protein and fiber on digestion, performance and carcass traits of sheep. Egyptian Journal Nutrition and Feeds, 1: (1): 23-32.

Taie, H. T., B. A. Ahmed and K. M. Kewan, 1996. Rumen activity and microbial protein synthesis as affected by dietary protein and fiber levels. Proc $9^{\text {th }}$ Sci. Conf. The Egyptian Society of Animal Production, Shebin El-Kom Menofyia, 11-13 Nov. 1996.

Talha, M.H.A., 1996. Nutritional studies on green forage Ph.D., Science. Faculty of Agriculture Science Animal Nutrition Ain Shams University. 
الأداء الإنتاجي للحملان النامية المغذاة علي سيلاج القمم النامية لقصب السكر(زعازيع القصب) وسيلاج أوراق بنجر السكر وسيلاج عيدان الذرة الخضراء الأبناء

عبد الرحيم إدريس علي سليمان، أحمد عبد الجليل بيومي، مصطفي أحمد علي عوض3 3 1- مركز البحوث الزرراعية، معطل بحوث الإنتاج الحيواني، الدقي، الجبيزة، 2- كلية الزيراعة، جامعة جنوب الوادي، قسم الإتـاج الحيوانسي ، قنا،

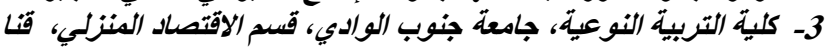

أجري هذا البحث لدراسة أداء النمو و معاملات الهضم للحملان المغذاة علي سبلاج عيدان الذرة الخضر اء ، سبلاج قمم قصب السكر وسيلاج

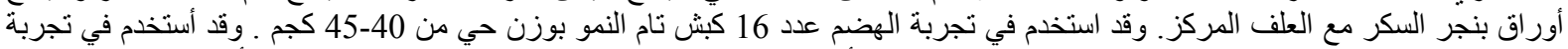

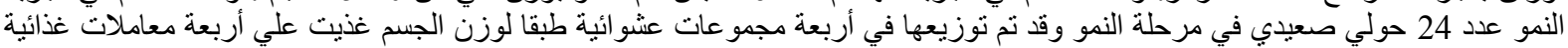
كالتالي:-

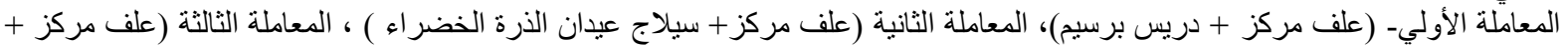

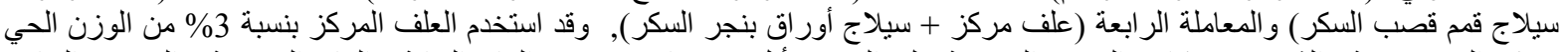

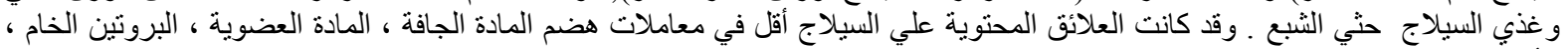

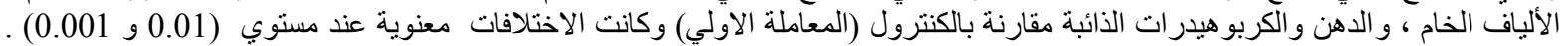

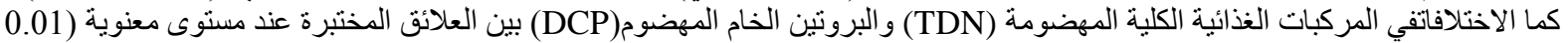

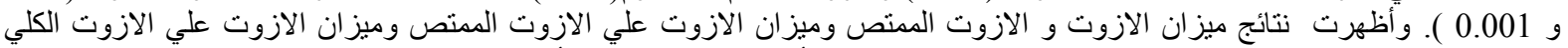

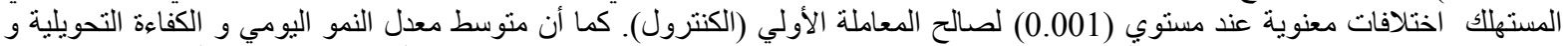

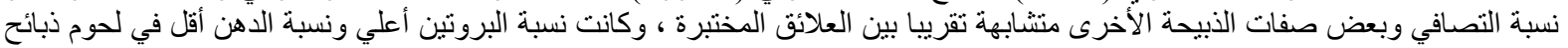

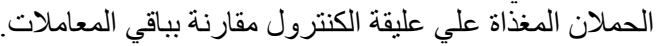

